Proceeding Paper

\title{
Characterization and Performance Analysis of Non-Metallic Oxide Nano-Fluids in Compound Parabolic Trough Solar Collectors ${ }^{\dagger}$
}

\author{
Muhammad Kaleem ${ }^{1}$, Muzaffar Ali ${ }^{2, *\left(\mathbb{D}, \text { Hamza Riaz }^{1} \text { and Javed Akhter }\right.}{ }^{3}$ \\ 1 Energy Engineering Department, University of Engineering and Technology, Taxila 47080, Pakistan; \\ Muhammad.kaleem2@students.uettaxila.edu.pk (M.K.); hamaz.riaz@students.uettaxila.edu.pk (H.R.) \\ 2 Mechanical Engineering Department, University of Engineering and Technology, Taxila 47080, Pakistan \\ 3 Mechanical Engineering Department, University of Chakwal, Chakwal 48800, Pakistan; \\ javed.akhter@uettaxila.edu.pk \\ * Correspondence: muzaffar.ali@uettaxila.edu.pk \\ + Presented at the 1st International Conference on Energy, Power, and Environment, Gujrat, Pakistan, \\ 11-12 November 2021.
}

Citation: Kaleem, M.; Ali, M.; Riaz, H.; Akhter, J. Characterization and

Performance Analysis of

Non-Metallic Oxide Nano-Fluids in Compound Parabolic Trough Solar Collectors. Eng. Proc. 2021, 12, 88. https://doi.org/10.3390/

engproc2021012088

Academic Editor: Shahid Iqbal

Published: 18 January 2022

Publisher's Note: MDPI stays neutral with regard to jurisdictional claims in published maps and institutional affiliations.

Copyright: (C) 2022 by the authors. Licensee MDPI, Basel, Switzerland. This article is an open access article distributed under the terms and conditions of the Creative Commons Attribution (CC BY) license (https:// creativecommons.org/licenses/by/ $4.0 /)$.

\begin{abstract}
Solar energy is a viable source to fulfill the energy demands of a solar rich country such as Pakistan. Various types of solar thermal technologies are being used around the world, including flat plate, evacuated tube, and compound parabolic trough collectors. However, the performance of these collectors is strongly influenced by the nature of work fluid. Utilization of nanofluids with high thermal conductivity is a very attractive way to further enhance the performance of solar collectors. Therefore, this study deals with the characterization and thermal performance enhancement of compound parabolic collectors (CPC) by using non-metallic nanofluids such as water-based multiwall carbon nano tubes $\left(\mathrm{H}_{2} \mathrm{O}-\mathrm{MWCNT}\right)$ with a thermal conductivity of $3000 \mathrm{~W} / \mathrm{m} \cdot \mathrm{K}$. In the current work, multiple tests are performed to analyze the thermal conductivity and stability of nanofluids through thermal analyzer and UV-Vis Spectroscopy, respectively. Test results show that the thermal conductivity of water-based MWCNT nanofluid is 37\% higher than water at a concentration of $0.075 \%$. Prepared nanofluids are then employed in CPC, and detailed experimentation is performed by varying the concentration of nanoparticles $(0.025,0.05,0.075 \%)$ and their flow rate $(0.015,0.02 \mathrm{~kg} / \mathrm{s})$. Maximum temperature difference of $10.5 \mathrm{oC}$ with volumetric concentration of $0.075 \%$ is achieved in experimental analysis at flow rate $0.015 \mathrm{~kg} / \mathrm{s}$. Thermal efficiency enhancement of $19.37 \%$ with volumetric concentration $0.075 \%$ is recorded as compared to water at flow rate $0.015 \mathrm{~kg} / \mathrm{s}$.
\end{abstract}

Keywords: nanofluids; non-metallic oxides; CPC; characterization of nanofluid; MWCNT

\section{Introduction}

In a research study, SWCNT/Water nanofluids were used in flat plate collector, and heat transfer enhancement of $95.12 \%$ and $26.25 \%$ was obtained for $0.3 \%$ and $0.1 \%$ volumetric concentration, respectively [1]. In another study, MWCNT/Water nanofluids were utilized and heat transfer enhancements of $16 \%, 21 \%$ and $34.13 \%$ were achieved for volumetric concentrations of $0.01 \%, 0.05 \%$ and $0.1 \%$ respectively [2]. Similarly, $0.05 \% \mathrm{wt} \%$ MWCNT/water nanofluids used in a heat-pipe-evacuated tube solar collector and maximum thermal efficiency of 55\% were achieved [3]. In another study, distilled-water-based graphene nanofluids were used in flat-plate solar collector and heat transfer enhancement of $24.09 \%$ was recorded for $0.1 \mathrm{wt} \%$ at flow rate of $1.5 \mathrm{~L} / \mathrm{min}$ [4]. In a similar study, SWCNT/water nanofluids were utilized in an evacuated tube solar collector and thermal efficiency of $93.43 \%$ for $0.2 \mathrm{vol} . \%$ at $0.025 \mathrm{~kg} / \mathrm{s}$ flow rate was recorded [5]. In another study, various nanofluids such as MWCNT/water, graphene/water, copper oxide/water, aluminum oxide/water, titanium oxide/water, and silicon oxide/water nanofluids were 
used in flat plate solar collector and 23.47\%, 16.97\%, 12.64\%, 8.28\%, 5.09\%, and 4.08\% thermal efficiencies of the collector were obtained, respectively [6]. In this study, effective thermal conductivity of water and Therminol-66-based MWCNT nanofluid was measured and thermal conductivity enhancement of $37 \%$ was found [7]. In another study, $44 \%$ enhancement in thermal efficiency was recorded by using Therminol ${ }^{\circledR} \mathrm{VP}-1$ based SWCNT nanofluids in parabolic trough solar collector [8]. Similarly, SWCNT/Water nanofluids are used in evacuated tube solar collector and $66 \%$ efficiency improvement with $0.2 \%$ volumetric concentration is recorded [9].

Unique work of this paper is the application of nonmetallic nanofluid in compound parabolic collector for real-time analysis of collector. In earlier studies, there is no application of nonmetallic nanofluids in compound parabolic solar collectors. In this study, the thermal conductivity of nonmetallic nanofluid is determined by using a TEMPOS thermal analyzer. The stability of these fluids is also analyzed with the help of UV-Vis spectrophotometer.

\section{Materials and Methods}

In this section, details about the selection of nanoparticles, preparation method, and experimental setup are presented.

\subsection{Selection of Nanoparticles}

The nanoparticles used in the experimental study were MWCNTs. The nanoparticles with 95\% purity, 10-20 nm particle size, 30-100 $\mu \mathrm{m}$ length, $165 \mathrm{~m}^{2} / \mathrm{g}$ specific surface area, $0.07 \mathrm{~g} / \mathrm{cm}^{2}$ bulk density and black color were purchased from NanoAmor (Nano structured and Amorphous Materials, Inc., Houston, TX, USA).

\subsection{Preparation of Nanofluids}

MWCNT/water nanofluids were prepared by two-step method with the help of magnetic stirrer, Ultra-Turrax T25 shear homogenizer and ultrasonic bath in several volumetric concentrations $(0.025,0.05$ and $0.075 \%)$. First of all, weighted nanoparticles were introduced into the base fluids and hand-stirred using a glass rod, and then magnetic stirrer at $40{ }^{\circ} \mathrm{C}$ and up to $650 \mathrm{rpm}$ was used to disperse particles into base fluids. In addition, the UltraTurrax T25 homogenizer was employed at 15,000 rpm to improve the homogenization of the mixture. Then, SDS was utilized in nanofluids as a surfactant to remove nanoparticle clusters and was placed in sonication bath for around $2 \mathrm{~h}$ at frequency of $40 \mathrm{KHz}$.

\subsection{Experimental Setup and Measurement Procedure}

The solar collector system performance relies on the area and the concentration ratio. The concentration ratio and collector area were 4.17 and $0.8 \mathrm{~m}^{2}$, respectively, for this collector. The length of the evacuated tube was $1.85 \mathrm{~m}$, and area was $0.2 \mathrm{~m}^{2}$. The experimental setup was placed east-west direction. MWCNT/water nanofluids and conventional fluids such as water were experimented with in CPC in a closed loop. The cold fluid was entered by the pump into the absorber, and the heat was exchanged with the absorber tube. This hot fluid was then collected at hot fluid storage tank placed, at the outlet of the absorber tube and then delivered back to the absorber entrance side. Thermocouples of the K type were fitted for temperature monitoring at the inlet and outlet of the absorber. The flow meter was combined with Arduino to measure fluid flow. Using the pyranometer, hourly solar radiation was monitored, and radiations lay in the range of $625 \mathrm{~W} / \mathrm{m}^{2}$ to $1012 \mathrm{~W} / \mathrm{m}^{2}$. The experimentation was held between 10:00 a.m. and 14:00 p.m., for $7 \mathrm{~h}$.

\section{Results and Discussion}

In this section, the thermal conductivity and UV-Vis spectroscopy measurements of the non-metallic oxide nanofluids are presented. The performance study of nanofluids is provided in terms of obtained temperature difference, and thermal efficiency of the system, under a subtropical climate of Taxila Pakistan. 


\subsection{UV-Vis Spectroscopy}

Spectral analysis through UV-Vis spectroscopy is a good technique to assess stability of nanofluids. UV-vis spectroscopy offers quantitative results consistent with the concentration of nanofluids. The UV and visible light are absorbed into the particulate fluid. The higher the absorption, the more the nanofluid is stable. Firstly, the gadget was calibrated with distilled water. Then, prepared nanofluid was inserted in the spectrophotometer in a small-band cell $(3.5 \mathrm{~mL})$ and examined for wavelengths of $300 \mathrm{~nm}$ to $700 \mathrm{~nm}$. Figure 1a shows the UV-vis spectrograph of $\mathrm{H}_{2} \mathrm{O}-\mathrm{MWCNT}$ nanofluid at $30^{\circ} \mathrm{C}$. Several peak values are obtained at different wavelengths. Maximum peak values were obtained at $399 \mathrm{~nm}$, $341 \mathrm{~nm}$ and $341 \mathrm{~nm}$ wavelengths with absorbance of $2.7,2.1$ and 1.4 at $0.075 \%, 0.05 \%$ and $0.025 \%$ volumetric concentrations, respectively.

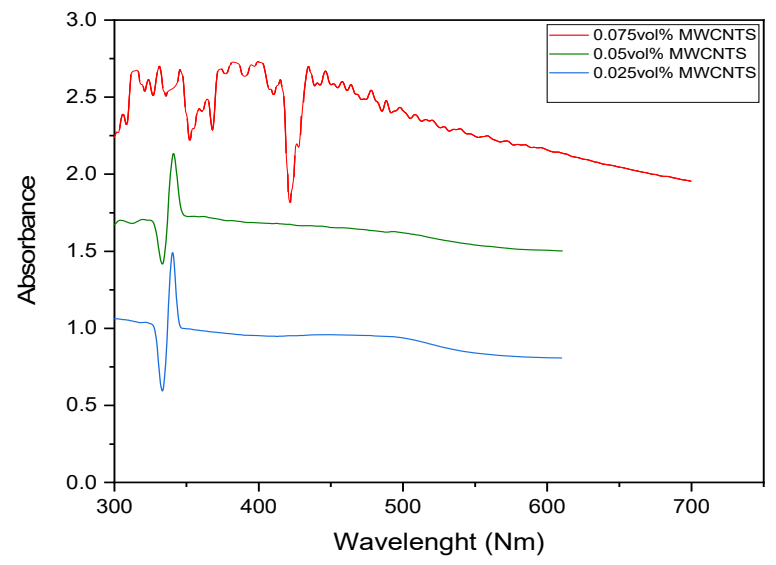

(a)

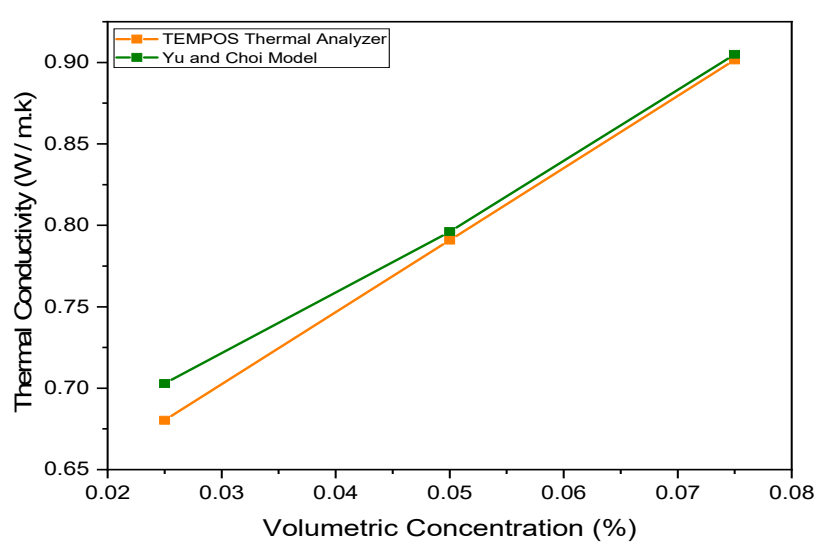

(b)

Figure 1. UV-vis spectroscopy (a) and thermal conductivity with different volumetric concentrations at $30{ }^{\circ} \mathrm{C}(\mathbf{b})$.

\subsection{Thermal Conductivity Measurement $(\mathrm{W} / \mathrm{m} \cdot \mathrm{K})$}

TEMPOS Thermal Analyzer Instrument developed by Decagon Devices Inc. measures thermal conductivity of nanofluids at several volumetric levels $(0.025,0.05,0.075 \%)$ at $30{ }^{\circ} \mathrm{C}$. It operates on the basis of the transient hot wire method (after $1 \mathrm{~min}$ of fluid stability, the TEMPOS Thermal Analyzer measure). The precision of the device is $\pm 10 \%$. The equipment is calibrated before the beginning of the experiment. For this experiment, the KS3 sensor was employed. Nanofluid thermal conductivity directly related to nanoparticles concentration, i.e., the thermal conductivity, rises by the increase in the volume fraction of the base fluid nanoparticles. The dispersion stability of the nanofluid is important because if there is no dispersion or weak dispersion stability of the nanofluid, the thermal conductivity values might be disturbed because the nanoparticles might stick to the needle of the KS-3 sensor and the results will be different to what is expected. TEMPOS Thermal Analyzer comparison of experimental data with analytical model of thermal conductivity of MWCNT $/ \mathrm{H}_{2} \mathrm{O}$ nanofluid at various concentrations is presented in Figure $1 \mathrm{~b}$. The results demonstrate that the analytical model and experimental results have the same trend. At $0.075 \mathrm{vol} \%$ maximum thermal conductivity obtained from TEMPOS Thermal Analyzer and analytical model are $0.9015 \mathrm{~W} / \mathrm{m} \cdot \mathrm{K}$ and $0.9282 \mathrm{~W} / \mathrm{m} \cdot \mathrm{K}$, respectively.

\subsection{Variation in Temperature Difference and Thermal Efficiency}

Figure 2a represents the change in temperature of MWCNT/Water nanofluid with multiple volumetric concentration and flow rate of 0.02 and $0.015 \mathrm{Kg} / \mathrm{s}$, respectively. There is significant increase in the change in temperature with usage of nanofluid. Maximum value is obtained for the maximum volumetric concentration of the nanoparticles in base fluid. The higher temperature difference is achieved by utilizing MWCNT/water nanofluid. Temperature differences of $7.52{ }^{\circ} \mathrm{C}$ and $10.12{ }^{\circ} \mathrm{C}$ are achieved for $0.025 \%$ volumetric con- 
centration at 0.02 and $0.015 \mathrm{~kg} / \mathrm{s}$, respectively, and temperature differences of $7.9^{\circ} \mathrm{C}$ and $10.5^{\circ} \mathrm{C}$ are achieved for $0.075 \%$ volumetric concentration at 0.02 and $0.015 \mathrm{~kg} / \mathrm{s}$, respectively. The maximum temperature differences such as $6.57^{\circ} \mathrm{C}$ and $6.11^{\circ} \mathrm{C}$ use water as a working fluid at flow rates of $0.015 \mathrm{~kg} / \mathrm{s}$ and $0.02 \mathrm{~kg} / \mathrm{s}$, respectively. Because nanofluids are large in terms of surface, they absorb more heat from the sun compared to water since the radiation hits their particles. In addition, nanoparticle bornin movement also enhances the possibility of absorbing more warmth from the sun. Figure $2 b$ represents the comparison of the thermal efficiencies of nanofluid obtained with mass flow rates of $0.02 \mathrm{~kg} / \mathrm{s}$ and $0.015 \mathrm{~kg} / \mathrm{s}$, with water and MWCNT/water as conventional fluids.

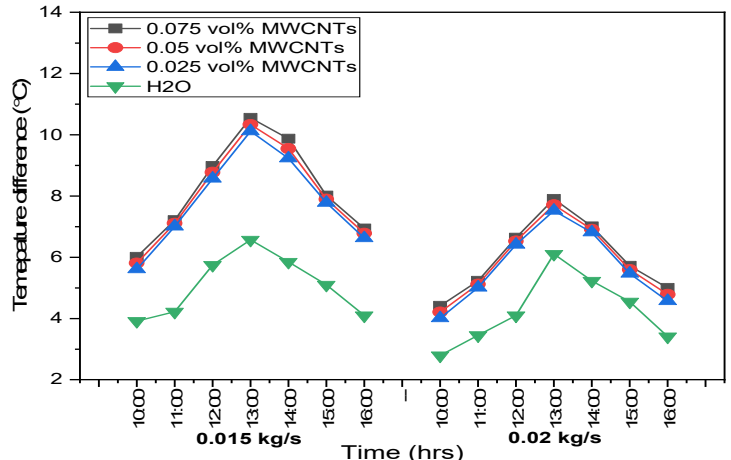

(a)

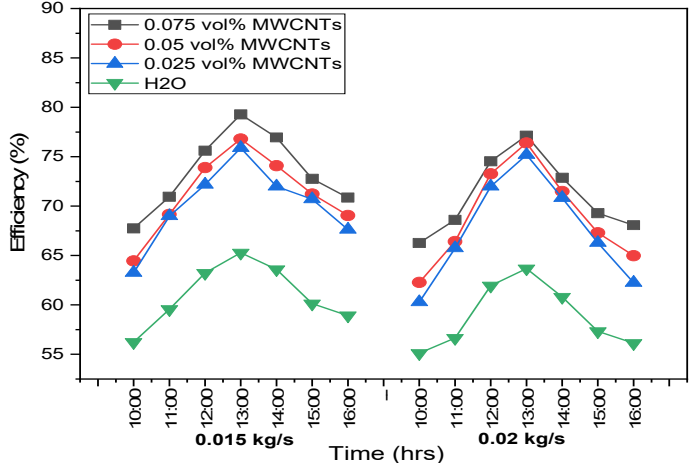

(b)

Figure 2. Variation in (a) temperature difference with flowrate and (b) efficiency with flowrate.

MWCNT/water exhibits higher thermal properties and better stability than other nanofluids, hence better thermal efficiency is obtained using it in CPC. Maximum thermal efficiency value is obtained at 13:00 p.m. Thermal efficiency of $75.1 \%$ and $75.8 \%$ is achieved for $0.025 \%$ volumetric concentration at 0.02 and $0.015 \mathrm{~kg} / \mathrm{s}$, respectively, and thermal efficiency of $77.1 \%$ and $79.2 \%$ are achieved for $0.075 \%$ volumetric concentration at 0.02 and $0.015 \mathrm{~kg} / \mathrm{s}$, respectively. Maximum thermal efficiency is $63.6 \%$ and $65.2 \%$ using water as a working fluid at flow rates of $0.015 \mathrm{~kg} / \mathrm{s}$ and $0.02 \mathrm{~kg} / \mathrm{s}$, respectively.

\section{Conclusions}

In this study, the stability and performance analysis of a CPC with non-metallic oxide based nanofluid is performed under real conditions of sub-tropical climate of Taxila, Pakistan. Analysis has been done with three volumetric concentrations (0.025, 0.05 and $0.075 \%)$ and two mass flow rates $(0.02$ and $0.015 \mathrm{~kg} / \mathrm{s})$. Nanofluids are found to be stable during the duration of experimentation hours, i.e., $7 \mathrm{~h}$ daily. Maximum thermal conductivity enhancement of $37.2 \%$ is noted for MWCNT/water with $0.075 \%$ volumetric concentration. The maximum temperature difference of $10.55^{\circ} \mathrm{C}$ is achieved by MWCNT/water nanofluid with $0.075 \%$ volumetric concentration at a lower flow rate of $0.015 \mathrm{~kg} / \mathrm{s}$. Enhancements of $19.37 \%$ and $16.23 \%$ in thermal efficiency are achieved by using non-metallic nanofluids at flow rates of $0.015 \mathrm{~kg} / \mathrm{s}$ and $0.02 \mathrm{~kg} / \mathrm{s}$, respectively.

Acknowledgments: Authors are thankful to Higher Education Commission of Pakistan for providing financial assistance under the program of "National Research Program for Universities- NRPU-10483" which helped a lot in completion of this research work.

\section{References}

1. Said, Z.; Saidur, R.; Sabiha, M.A.; Rahim, N.A.; Anisur, M.R. Thermophysical properties of Single Wall Carbon Nanotubes and its effect on exergy efficiency of a flat plate solar collector. Sol. Energy 2015, 115, 757-769. [CrossRef]

2. Eltaweel, M.; Abdel-Rehim, A.A. Energy and exergy analysis of a thermosiphon and forced-circulation flat-plate solar collector using MWCNT/Water nanofluid. Case Stud. Therm. Eng. 2019, 14, 100416. [CrossRef]

3. Eltaweel, M.; Abdel-Rehim, A.A.; Attia, A.A.A. Energetic and exergetic analysis of a heat pipe evacuated tube solar collector using MWCNT/water nanofluid. Case Stud. Therm. Eng. 2020, 22, 100743. [CrossRef] 
4. Kumar, L.H.; Kazi, S.N.; Masjuki, H.H.; Zubir, M.N.M.; Jahan, A.; Bhinitha, C. Energy, exergy and economic analysis of liquid flatplate solar collector using green covalent functionalized graphene nanoplatelets. Appl. Therm. Eng. 2021, 192, 116916. [CrossRef]

5. Sabiha, M.A.; Saidur, R.; Hassani, S.; Said, Z.; Mekhilef, S. Energy performance of an evacuated tube solar collector using single walled carbon nanotubes nanofluids. Energy Convers. Manag. 2015, 105, 1377-1388. [CrossRef]

6. Verma, S.K.; Tiwari, A.K.; Chauhan, D.S. Experimental evaluation of flat plate solar collector using nanofluids. Energy Convers. Manag. 2017, 134, 103-115. [CrossRef]

7. Singh, T.; Almanassra, I.W.; Olabi, A.G.; Al-Ansari, T.; McKay, G.; Atieh, M.A. Performance investigation of multiwall carbon nanotubes based water/oil nanofluids for high pressure and high temperature solar thermal technologies for sustainable energy systems. Energy Convers. Manag. 2020, 225, 113453. [CrossRef]

8. Mwesigye, A.; Yllmaz, İ.H.; Meyer, J.P. Numerical analysis of the thermal and thermodynamic performance of a parabolic trough solar collector using SWCNTs-Therminol@VP-1 nanofluid. Renew. Energy 2018, 119, 844-862. [CrossRef]

9. Mahbubul, I.M.; Khan, M.M.A.; Ibrahim, N.I.; Ali, H.M.; Al-Sulaiman, F.A.; Saidur, R. Carbon nanotube nanofluid in enhancing the efficiency of evacuated tube solar collector. Renew. Energy 2018, 121, 36-44. [CrossRef] 